\title{
Women Entrepreneurs In Malaysia: What Drives Them Venturing Into Business
}

\author{
Azlin Shafinaz Arshad, Afiza Azura Arshad, Marziah Mokhtar, Arlinah Abdul Rashid
}

\begin{abstract}
The number of women venturing into business is increasing. There are numerous factors at play for why women are starting to assert themselves in business. The study aims to explore the motivating factors of women venturing into business in Malaysia. Survey questionnaires were collected from 150 women business owner using convenience sampling. Descriptive analysis and factor analysis were employed in analyzing the data. Findings revealed the most critical factor motivating these women to venture into business was for them to be able to pass on the business to the next successor. Venturing into business for fun was found to be the least important factors. Motivation factors were factor analyzed to determine the main groupings of variables that lead women entrepreneurs to venture into business. Factor analysis conducted led motivation factors into two main factors; Business Achievements and Individual/Personal \& Family Influence. This study will help improve strategy for women entrepreneurs to start business.
\end{abstract}

Index Terms: Entrepreneur, Entrepreneurship, Motivation Facto, Women Entrepreneur.

\section{INTRODUCTION}

Many nations have recognized entrepreneurship among the important factors of economic growth, productivity, innovation and employment. The importance of entrepreneurship is undeniable since entrepreneurship is the backbone of many developing and developed countries [1]. Women's involvement in employment is crucial to move a country from developing to a developed one [2]. Entrepreneurship development has added much momentum as it brings economic growth, social stability, and employment opportunity as well as eradicates poverty [3]. There is no doubt entrepreneurship requires equal participation and opportunities to both men and women. However, there exists differences between these two groups when it comes into business [4]. Alam \& Jani [5] argued the growth of women venturing into business is still significantly lower compered to men. Businesses owned by women was not given same opportunities since entrepreneurship are always associated with men [6]. It was further emphasized that women entrepreneurs tend to view businesses differently with male entrepreneurs [7].

Revised Manuscript Received on April 19, 2019.

Azlin Shafinaz Arshad, senior lecturer, Malaysian Academy of SME \& Entrepreneurship Development (MASMED), Universiti of Teknologi MARA (UiTM), Selangor, Malaysia

Afiza Azura Arshad, Senior Lecturer, Economics at Faculty of Business and Management, Universiti Teknologi MARA, Selangor, Malaysia.

Marziah Mokhtar, Senior Lecturer, Centre of Foundation Studies (CFS), Universiti of Teknologi MARA (UiTM), Selangor, Malaysia

Arlinah Abdul Rashid, Senior Lecturer in Economics, Arshad Ayub Graduate Business School, Universiti Teknologi MARA, Selangor, Malaysia
Women contribution toward a country's development has also been acknowledged worldwide [8,9]. Accordingly, the number of women becoming entrepreneur has improved from year to year $[10,11]$. Nevertheless, the percentage of women entrepreneurs according to countries ranges between $1 \%$ to $40 \%$ depending on economic development of a country. Many studies on women entrepreneurs have been conducted all over the world [12-16]. Nevertheless, studies on women entrepreneurs in Malaysia especially in identifying their motives to start a business are still limited and inadequate $[5,8,17]$. Thus, the present study tries to fill the gap by conducting study on women entrepreneurs which focusses on motivation factors.

\section{LITERATURE REVIEW}

Women today are not restricted living in the traditional way since the number of women involved in business are huge and many of them are said to be success [18]. Ademokun and Ajayi [19] explained woman entrepreneur is the one heading and initiating the business enterprise while Goyal and Parkash [20] claimed women entrepreneur is referred to woman, who develop, manage and operate a business venture. Contribution of women entrepreneur towards a country's development and growth is undeniable [18]. Involvement of women in nations' employment is crucial in transforming a country to developed country from developing country [2].

There are numerous reasons why women involved in business. Factors such as determination, moral support, capability, confidence, affluence, freedom, hardworking [21]. Psychological motives which comprise of selfsatisfaction, independence and availability of financing are the main factors motivate women involved in business [22]. In another study by Raman, Anantharaman [23] the determinants of women entrepreneur that motivates them are grouped into economic, work, social, individual and entrepreneurial factors. Women entrepreneur is motivated strongly by factors such as the need of having power, ability to make logical and wise decision and they want to change [24]. Social and cultural factors, economic factors and legal and administrative factors are the drivers motivating women involved in business [18]. Profit, technical skill possessed,

Published By: 
previous experience and advises from family members have also been discovered to be among the motivating factors motivate women entrepreneurs to go into business [25]. Kumar and Patrick [26] found factors influencing and motivating women entrepreneur to start business are internal, external and engagement for instance perks \& rewards and education \& competencies. Factors such as entrepreneurs' characteristics, social and economic are described to influence women entrepreneur starting a business venture [27].

\section{METHODOLOGY}

Quantitative study using self-administered questionnaires were employed and distributed to women entrepreneurs in Malaysia. Respondents were requested to state their agreement on the statement using Likert Scale ranges from "Strongly Disagree to Strongly Agree". Higher mean scores demonstrate the items are the most important while the lowest mean indicate the items is the least important. This study adopts the previous survey questionnaire, a popular research instruments commonly used in many earlier studies and tested in many countries [28-32]. A total of 150 questionnaires were distributed using convenience sampling as it is the easiest method to reach and access the sample. However, 118 responses can only be used for data analysis representing 78.6 percent response rate. The data obtained were tested with SPSS statistical software for descriptive analysis, factor analysis and reliability analysis. Factor analysis was employed in the study to identify whether motivations factors can be combined on significant factors. Keiser-Meyer-Olkin [KMO] is calculated using principal component analysis extraction method with Varimax rotation. In addition, calculation for summated score was also conducted to see which factors influence women entrepreneurs the most.

\section{RESULTS \& FINDINGS}

From the demographic profile, the study found that women entrepreneurs above 40 years of age constitute $58.5 \%$ while the balance of $41.5 \%$ is below 40 years old. From a total of 118 respondents, $52.5 \%$ are married, $25.4 \%$ are divorced, $11.9 \%$ are separated while $10.2 \%$ are still single. The education background of these women entrepreneurs is Diploma (9\%) followed by Degree $(32.7 \%$ ) and Master and above (5.8\%). Only 38.1\% respondents had tertiary education. Many of these women entrepreneurs registered their business as sole proprietorship (72\%), followed by private limited company (14.4\%) and partnership (13.6\%). The business location of women entrepreneurs concentrated in the central region (46.4\%) followed by Southern region (24.6\%), Northern region $(17.8 \%)$ and Eastern Malaysia $(10.2 \%)$ while only $0.8 \%$ of the business located in the East coast (8\%).

Table 1 presents the mean scores and standard deviation for 11 motivation factors driving women entrepreneurs to venture into business. The results indicated women entrepreneurs in Malaysia agreed that these factors do motivate them to go into business. It was evidenced in the study where all motivation factors had a mean score of above 4 except for one factor with a mean score of 3.24 which is "To have fun". The main factor that is crucial to women entrepreneurs is "To build a business to pass on" as it generates the highest mean value of 4.40 followed by three other factors; "To prove I can do it", "To increase my income" and "To be closer to my family" each generating mean score of 3.40. The lowest mean score observed in Table 1 is "To have fun" $(M=3.24)$.

Table 1: Mean Scores for Motivation Factors

\begin{tabular}{lcc}
\hline \multicolumn{1}{c}{ Motivation factor } & $\begin{array}{c}\text { Mean } \\
\text { Score }\end{array}$ & $\begin{array}{c}\text { Standard } \\
\text { deviation }\end{array}$ \\
\hline To be my orn boss & 4.25 & .847 \\
To be able to use nyy previous & 4.19 & .727 \\
experience and training & & \\
To prove I can do it & 4.34 & .682 \\
To increase my income & 4.34 & .695 \\
To provide jobs to family & 4.06 & .936 \\
members & & \\
For my orn satisfaction and & 4.28 & .738 \\
growth & & \\
SoI rill always havejob security & 4.26 & .672 \\
To brild a business to pass on & 4.40 & .681 \\
To maintain my personal & 4.27 & .649 \\
fresdom & & \\
To be closer to my family & 4.34 & .754 \\
To have fun & 3.24 & 1.363 \\
\hline
\end{tabular}

In identifying the main factors motivating women entrepreneurs to venture into business, factor analysis was conducted as shown in Table 2. The Keiser-Meyer-Olkin (KMO) value indicates the adequacy of sampling and the data is significant in factor analysis. From the 11 initial factors, the factor analysis use Principal Component Analysis with varimax rotation in which only items that loaded with absolute values greater than 0.6 are shown [33]. The factor analysis led to two factors; Business Accomplishment and Individual/ Personal \& Family Influence which cumulatively explain 62.17 percent of the variance. One factor was named "Business Accomplishment" where it comprises of factor "To increase my income", "To prove I can do it" and "To be able to use my past experience and training" which explains 52.28 percent of variance while the other factor is referred as "Individual/ Personal \& Family Influence" and contains 5 factors; "For my own satisfaction and growth", "To provide jobs to family members", "To be closer to my family", To have fun" and "I will always have job security" and accounts for 9.88 percent of variance. In addition to factor analysis, the reliability test was also calculated where value below 0.7 are removed [34]. The results from the reliability test indicate both factors to be above the recommended value. 
Table 2: Factor Analysis and Reliability Analysis for Success Factors

\begin{tabular}{|c|c|c|}
\hline \multirow[t]{2}{*}{ Motivation Factors } & \multicolumn{2}{|c|}{ Factor } \\
\hline & 1 & 2 \\
\hline To increase my income & .858 & \\
\hline To prove I can do it & .843 & \\
\hline $\begin{array}{l}\text { To be able to use my past experience and } \\
\text { training } \\
\text { To be my own boss [*] }\end{array}$ & .784 & \\
\hline For my own satisfaction and growth & & .795 \\
\hline To providejobs to family members & & .775 \\
\hline $\begin{array}{l}\text { To be closer to my family } \\
\text { To have fun factor }\end{array}$ & & $\begin{array}{l}.698 \\
.636\end{array}$ \\
\hline So I will always havejob security & & .601 \\
\hline \multicolumn{3}{|l|}{$\begin{array}{l}\text { To maintain my personal freed om }\left[{ }^{*}\right] \\
\text { To build a business to pass on }\left[{ }^{*}\right]\end{array}$} \\
\hline Kaiser-Meyer-Olkin [KMO] & \multicolumn{2}{|c|}{0.820} \\
\hline Eigenvalue & 6.274 & 1.186 \\
\hline Cumulative Variance Explained [\%] & 52.28 & 9.88 \\
\hline Cronbach's Alpha [dimension] & .845 & .776 \\
\hline Overall Cronbach's Alpha & \multicolumn{2}{|c|}{.833} \\
\hline
\end{tabular}

[*] L oadings below 0.6

\section{CONCLUSION}

Findings from present study indicate women entrepreneurs in Malaysia agreed that all the motivation factors listed were of importance to them to venture into business. This was evidenced from the mean score for all motivation factors were above 4 with the exception for one factor "To have fun" with $M=3.24$. Women entrepreneurs in Malaysia indicate their main motivation to venture into business is "To build a business to pass on" as it demonstrates the highest mean score of 4.40 compared to other factors. This finding however, opposed with few earlier studies [29, 30, 32] where all the studies revealed the most crucial factor entrepreneurs venture into business was because "to increase income". However, similar findings were found where entrepreneurs in Sudan demonstrate the most crucial factor is to provide jobs to family members and not to increase income [35]. The least crucial factor in motivating entrepreneurs to venture in business discovered in this study were in line with previous studies which is "to have fun" [29, 30, 35].

Factor analysis conducted on the motivation factors revealed two factors were observed. Three factors were "To increase my income", "To prove I can do it" and "To be able to use my past experience and training"- were grouped together and named as "Business Accomplishment". Another factor is labelled as "Individual/ Personal \& Family Influence" which comprise of factors such as "For my own satisfaction and growth", "To provide jobs to family members", "To be closer to my family", "To have fun" and "So I will always have job security". Findings of this study contrast with studies in Serbia and in Turkey as the factor analysis in both studies led to four factors [29-30].

This study only focuses on women entrepreneurs. Hence, it is recommended future researcher to conduct study on male entrepreneurs to determine whether there are any similarities or differences on factors that motivate them to venture into business. A qualitative study using in depth interviews can also be considered for future research in understanding on the motivation factors of women entrepreneurs. Future studies may want to use longitudinal design and use some other motivation factor in their study. In addition, others may want to delve into challenges women entrepreneurs face when they go into business

\section{ACKNOWLEDGMENT}

The study is supported by University of Technology MARA under LESTARI Research Grant 2017 [600IRMI/Dana KCM 5/3/LESTARI [161/2017] entitled Women-Owned SMEs: Determining Their Motivational Factors Starting Up Business.

\section{REFERENCES}

1. Ramadani V, Hisrich RD, Gërguri-Rashiti S. Female entrepreneurs in transition economies: insights from Albania, Macedonia and Kosovo. World Review of Entrepreneurship, Management and Sustainable Development. 2015;11[4]:391-413.

2. Hassan K, Yusof R. Women in Economic and Social Transformation Era: Issues and Challenges: UUM Press; 2014.

3. Rathna C, Badrinath V, Anushan S. A Study on entrepreneurial motivation and challenges faced by women entrepreneurs in Thanjavur district. Indian Journal of science and technology. 2016;9[27]:1-10.

4. Mustapha M. Challenges and success factors of female entrepreneurs: Evidence from a developing country. International Review of Management and Marketing. 2016;6[4S]:224-31.

5. Alam SS, Jani MFM, Omar NA. An empirical study of success factors of women entrepreneurs in southern region in Malaysia. International Journal of Economics and Finance. 2011;3[2]:166-75.

6. Salleh Z, Osman MHM. Goal orientations and typology of women entrepreneurs. Jurnal Kemanusiaan. 2007;5[2].

7. Teoh WM-Y, Chong S. Improving women entrepreneurs in small and medium enterprises in Malaysia: policy recommendations. Communications of the IBIMA 2008;2[5]:31-8.

8. Abdul M, Gunasagaran K, Kamarudin NA, Mizanur M. Critical success factors and challenges of women entrepreneurs in Klang Valley, Malaysia. Journal of Advanced Research in Business and Management Studies. 2017;6[1]:11.

9. Mitchelmore S, Rowley J. Entrepreneurial competencies of women entrepreneurs pursuing business growth. Journal of small business and enterprise development. 2013;20[1]:125-42.

10. Mattis MC. Women entrepreneurs: out from under the glass ceiling. Women in management review. 2004;19[3]:154-63.

11. Rehman S, Azam Roomi M. Gender and work-life balance: a phenomenological study of women entrepreneurs in Pakistan. Journal of Small Business and Enterprise Development. 2012;19[2]:209-28.

12. Allen S, Truman C. Women in business: Perspectives on women entrepreneurs: Routledge; 2016.

13. Hasan FS, Almubarak MMS. Factors influencing women entrepreneurs' performance in SMEs. World Journal of Entrepreneurship, Management and Sustainable Development. 2016;12[2]:82-101.

14. Meliou E, Edwards T. Relational practices and reflexivity: Exploring the responses of women entrepreneurs to changing household dynamics. International Small Business Journal. 2018;36[2]:149-68. 
15. Rey-Martí A, Porcar AT, Mas-Tur A. Linking female entrepreneurs' motivation to business survival. Journal of Business Research. 2015;68[4]:810-4.

16. Welsh DH, Memili E, Kaciak E. An empirical analysis of the impact of family moral support on Turkish women entrepreneurs. Journal of Innovation \& Knowledge. 2016;1[1]:3-12.

17. Mutalib RA, Arshad R, Ismail N, Ahmad Z. Women and entrepreneurship: An overview of women entrepreneurship programs in Malaysia. JGD Special Issue on Social Entrepreneurship. 2015;11:15-28.

18. Kamaruddin L, Arshad AS, Osman CA, Buyong SZ. An Exploratory Study of Malaysian Women Entrepreneurs: What Drives Them into Business. ASEAN Entrepreneurship Journal. 2018;4[2]:13.

19. Ademokun F, Ajayi O. Entrepreneurship development, business ownership and women empowerment in Nigeria. Journal of Business Diversity. 2012;12[1]:7287.

20. Goyal M, Parkash J. Women entrepreneurship in Indiaproblems and prospects. International Journal of Multidisciplinary Research. 2011;1[5]:195-207.

21. Matharu SK, Changle R, Chowdhury A. A Study of Motivational Factors of Women Entrepreneurs. IUP Journal of Entrepreneurship Development. 2016;13[1]:33.

22. Nordin M. Woman in business: Determinants for venturing in Malaysian SMEs. Retrieved December. 2005;6:2006.

23. Raman K, Anantharaman RN, Jayasingam S. Motivational factors affecting entrepreneurial decision: A comparison between Malaysian women entrepreneurs and women non entrepreneurs. Communications of the IBIMA. 2008;2[12]:85-9.

24. Chamorro-Premuzic T, Rinaldi C, Akhtara R, Ahmetoglu G. Understanding the Motivations of Female Entrepreneurs. Journal of Entrepreneurship \& Organization Management. 2013;3[01].

25. Suganthi J. Influence of motivational factors on women entrepreneurs in SMEs. Asia Pacific Business Review. 2009;5[1]:95-104.

26. Kumar S, Patrick HA. Motivating Factors That Influence Women Entrepreneurs. International Journal of Research in Business Management. 2018;6[4]:15.

27. Cavada MC, Bobek V, Ma?ek A. Motivation factors for female entrepreneurship in Mexico. Entrepreneurial Business and Economics Review. 2017;5[3]:133-48.

28. Hung CM, Katsioloudes MI. Cultural context and the Vietnamese-American entrepreneurial experience. Journal of Transnational Management Development. 2002;7[2]:37-46.

29. Benzing C, Chu HM, Kara O. Entrepreneurs in Turkey: A factor analysis of motivations, success factors, and problems. Journal of small business management. 2009;47[1]:58-91.

30. Stefanovi? I, Rankovi? L, Proki? S. Entrepreneurs' motivational factors: Empirical evidence from Serbia. Serbian Journal of Management. 2011;6[1]:73-83.

31. Uddin R, Bose T. Motivation, success factors and challenges of entrepreneurs in Khulna City of Bangladesh. European Journal of Business and Management. 2013;5[16]:148-57.

32. Zimmerman MA, Chu HM. Motivation, success, and problems of entrepreneurs in Venezuela. Journal of Management Policy and Practice. 2013;14[2]:76-90.

33. Hair J, Black W, Babin B, Anderson R, Tatham R. Multivariate data analysis . Cranbury: NJ: Pearson Education; 2009.

34. Cortina JM. What is coefficient alpha? An examination of theory and applications. Journal of applied psychology. 1993;78[1]:98.
35. Ibrahim SB, Essa EA. Motivation to Become Entrepreneurs: An Exploratory Study. Journal of Economic and Management Sciences. 2018;19[1]:7.

\section{AUTHORS PROFILE}

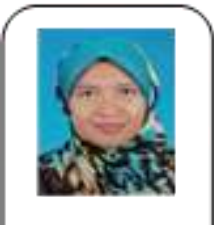

Azlin Shafinaz Arshad is a senior lecturer at Malaysian Academy of SME \& Entrepreneurship Development (MASMED), Universiti of Teknologi MARA (UiTM). Previously she holds the post as the Head of Department for Entrepreneurial Education in 2016 and in 2018 as the Head of Department for Entrepreneurial Research. She obtained her Doctor of Philosophy (Management) from Universiti Teknologi Malaysia (UTM) in 2016, Master of Business Administration from Universiti Teknologi MARA (UiTM), BBA (Hons) Finance from Universiti Teknologi MARA (UiTM) and Diploma in Accountancy also from Universiti MARA Malaysia (UiTM). Her research interest is in Entrepreneurship, Entrepreneurial Orientation, SMEs, Women Entrepreneurship, Entrepreneurial Intention, Leadership. She is a lifetime member of Malaysia Economics Association and Malaysian Consumers and Family Economics Association.

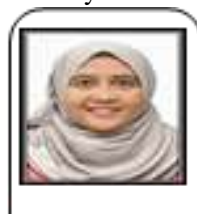

Afiza Azura Arshad is Senior Lecturer in Economics at Faculty of Business and Management, Universiti Teknologi MARA, Malaysia. She obtained her Master of Business Administration from Universiti Teknologi MARA and Bachelor of Science from University of Missouri, Rolla United States of America. She is a lifetime member of Malaysia Economics Association and Malaysian Consumers and Family Economics Association.

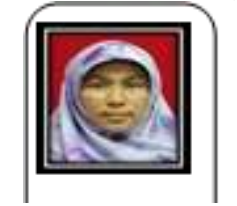

Marziah Mokhtar is a senior lecturer at Centre of Foundation Studies (CFS), Universiti of Teknologi MARA (UiTM). Previously she holds the position as Assistant Secretary of Innovation and Commercialization Unit, Ministry of Science, Head of Commercialization Unit at Research Innovation Unit, Universiti Teknologi MARA (UiTM) and now as MASMED Coordinator at Centre of Foundation Studies (CFS), Universiti of Teknologi MARA (UiTM). She obtained her Doctor of Philosophy (International Trade) from Universiti Kebangsaan Malaysia (UKM), Master of Business Administration from Universiti Teknologi MARA and a degree in Public Policy from Universiti Kebangsaan Malaysia (UKM). She is a lifetime member of Malaysia Economics Association and Malaysian Consumers and Family Economics Association.

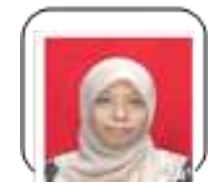

Arlinah Abdul Rashid is Senior Lecturer in Economics at Arshad Ayub Graduate Busines School, Universiti Teknologi MARA, Malaysia. She holds a $\mathrm{PhD}$ in Economics from Lancaster University, United Kingdom, Master of Business Administration from Universiti Teknologi MARA and a degree in Economics from the University of Michigan, Ann Arbor. Her research interest are managerial economics, environmental economics and applied economics. She is a lifetime member of Malaysia Economics Association and Malaysian Consumers and Family Economics Association. 